\title{
Rancangan Arsitektur Enterprise Resource Planning (ERP) Sekolah Berdasarkan Capability Maturity Model (CMM)
}

\author{
Mohammad Malik Fajar ${ }^{1, *}$, Muhammad Ilman Nurhadi², Muhamad Roni Kurniawan³, Muhammad \\ Ainul Yaqin ${ }^{4}$ \\ Jurusan Teknik Informatika, Universitas Islam Negeri Maulana Malik Ibrahim, Indonesia \\ ${ }^{1}$ mohammadmalikfajar17@gmail.com; ²nurhadiilman12062000@gmail.com; ${ }^{3}$ muhamadroni16092000 @ gmail.com; \\ 4yaqinov@gmail.com \\ * corresponding author
}

INFO ARTIKEL

\section{Sejarah Artikel}

Diterima: 23 Desember 2019

Direvisi: 16 April 2020

Diterbitkan: 30 Agustus 2020

Kata Kunci

Sekolah

ERP

CMM

\section{ABSTRAK}

Sekolah adalah suatu lembaga pendidikan yang dirancang secara khusus untuk mendidik siswa dalam pengawasan para guru. Setiap sekolah memerlukan suatu sistem yang bisa membuat proses-proses di dalamnya menjadi saling terintegrasi dengan baik. Sistem tersebut adalah sistem yang mengacu pada konsep Enterprise Resource Planning (ERP). ERP ini adalah sebuah sistem informasi yang bisa menghubungkan proses-proses yang ada di sekolah. Namun proses-proses yang ada di sekolah memiliki tingkat kematangan. Dalam pengukuran tingkat kematangan ini lah digunakannya Capability Maturity Model (CMM). Metode penelitian yang digunakan pada penelitian ini adalah menggunakan metode FAST. Metode FAST yang digunakan ini terdiri dari scope definition, problem analysis, requirements analysis, dan logical design. Hasil akhir dari penelitian ini adalah sebuah rancangan arsitektur ERP sekolah dengan penjelasan masing-masing fitur pada sistem informasinya berdasarkan CMM. Sehingga diharapkan rancangan tersebut bisa diimplementasikan di sekolah dan meningkatkan kualitas dari sekolah tersebut.

\section{PENDAHULUAN}

Teknologi informasi semakin berkembang pada era ini membuat segala sesuatu menjadi lebih cepat. Salah satu teknologi informasi yang saat ini digunakan adalah Enterprise Resource Planning (ERP). ERP merupakan sebuah sistem informasi yang dikhususkan bagi perusahan dalam bidang manufaktur maupun jasa yang memiliki peran untuk menghubungkan dan menjalankan suatu proses bisnis yang saling berhubungan dengan aspek operasi, produksi maupun distribusi di perusahaan tersebut[1]. Terdapat banyak penyedia sistem ERP, salah satunya adalah SAP (System, Applications, Production in Data Processing) yang menyediakan beberapa modul ERP yang dapat digunakan perusahaan sesuai dengan kebutuhannya. Menurut SAP-ERP, ada 6 bagian utama dalam ERP yaitu penjualan dan distribusi, perencanaan produksi, manajemen material, pelaksanaan manufaktur, akuntansi keuangan, dan pengendalian[2].

Arsitektur ERP adalah sebuah rancangan dalam membangun atau menyusun sebuah sistem informasi yang didalamnya berisi bagaimana cara memanajemen proses bisnis dan bagaimana alur proses bisnis yang ada pada suatu instansi itu berlangsung. Penerapan ERP di sekolah dapat digunakan untuk menghubungkan proses-proses bisnis yang ada di sekolah. Proses bisnis adalah sekumpulan aktivitas yang terstruktur dan terkait yang menghasilkan layanan atau produk tertentu untuk pelanggan tertentu[3]. Dengan penerapan ERP ini, maka akan mempermudah organisasi dalam komunikasi maupun berbagi data antar organisasi di 
sekolah. Sehingga akan membuat proses pengelolaan manajemen di sekolah lebih efektif dan efisien. Namun, proses bisnis pada masing-masing sekolah memiliki tingkat kematangan yang berbeda. Ini terjadi karena masing-masing sekolah memiliki kemampuan dan standar yang berbeda. Maka dari itu, dalam perancangan arsitektur ERP sekolah ini akan dibuat berdasarkan CMM. Capability maturity model disingkat CMM merupakan sebuah mekanisme kualifikasi software develop house yang dapat memberikan gambaran tentang kemampuan perusahaan tersebut dalam melakukan pengembangan perangkat lunak[4]. Dengan menggunakan tingkat kematangan pada perancangan arsitektur ERP sekolah, maka sekolah akan mengetahui tingkat kematangan pengelolaan manajemen mereka. Dan hal tersebut juga bisa memudahkan sekolah dalam mengembangkan pengelolaan manajemen mereka dengan melihat kunci area proses pada tiap levelnya. Pada tingkat kematangan berdasarkan CMM memiliki lima level. Lima level kematangan ini akan digunakan sebagai acuan dalam pembuatan arsitektur ERP sekolah. Hasil dari penelitian ini adalah rancangan arsitektur ERP sekolah dengan penjelasan masing-masing fitur pada sistem informasinya berdasarkan CMM.

\section{METODE}

Penelitian ini menggunakan metode FAST (Framework for the Application of System Thinking). Pada metode FAST ini memiliki beberapa tahapan sebagai berikut:

1) Scope Definition. Tahapan Scope Definition adalah tahapan dalam mendefinisikan ruang lingkup permasalahan.

2) Problem Analysis. Tahapan Problem Analysis adalah tahapan mempelajari sistem informasi yang sudah ada di sekolah dan menganalisis temuan-temuan agar dapat menemukan pemahaman yang lebih mendalam berdasarkan masalah yang ada.

3) Requirement Analysis. Tahapan requirement analysis adalah tahapan penelitian dalam menentukan dan menganalisis kebutuhan yang ada pada sistem informasi.

4) Logical Design. Tahapan logical design adalah tahapan penelitian merubah kebutuhan pada sistem informasi menjadi rancangan sistem informasi.

\section{HASIL DAN PEMBAHASAN}

Scope Definition. Ruang lingkup pada penelitian ini adalah merancang arsitektur ERP sekolah dengan penjelasan masing-masing fitur pada sistem informasinya berdasarkan CMM.

\section{Problem Analysis}

Menurut SAP-ERP, ada enam bagian utama dalam ERP yaitu penjualan dan distribusi, perencanaan produksi, manajemen material, pelaksanaan manufaktur, akuntansi keuangan, dan pengendalian. enam bagian tersebut terdapat pada Gambar 1. 


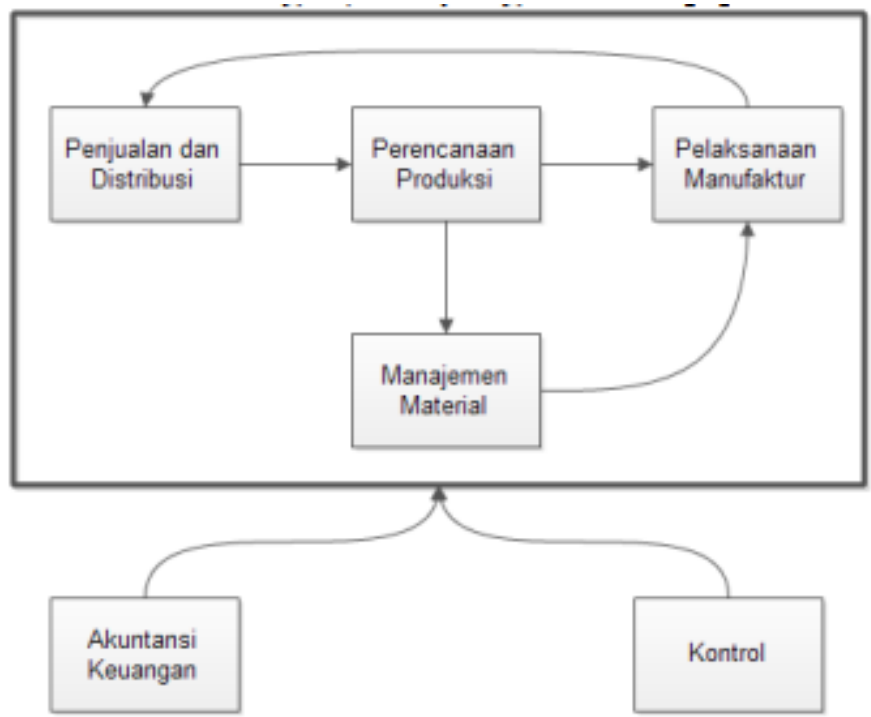

Gambar 1. Siklus SAP-ERP

Dari enam bagian utama pada ERP seperti yang ditunjukkan pada gambar 1 masingmasing bagian memiliki proses. Proses yang dimaksud kali ini adalah proses-proses yang ada di sekolah. Proses-proses pada masing-masing sekolah ternyata memiliki tingkat kematangan proses yang berbeda. Untuk dapat mengukur tingkat kematangan proses dalam suatu lingkungan sekolah, diperlukan pendefinisian setiap level Capability Maturity Model (CMM). Terdapat lima level dalam Capability Maturity Model (CMM). Lima level tersebut bisa dilihat pada Gambar 2.

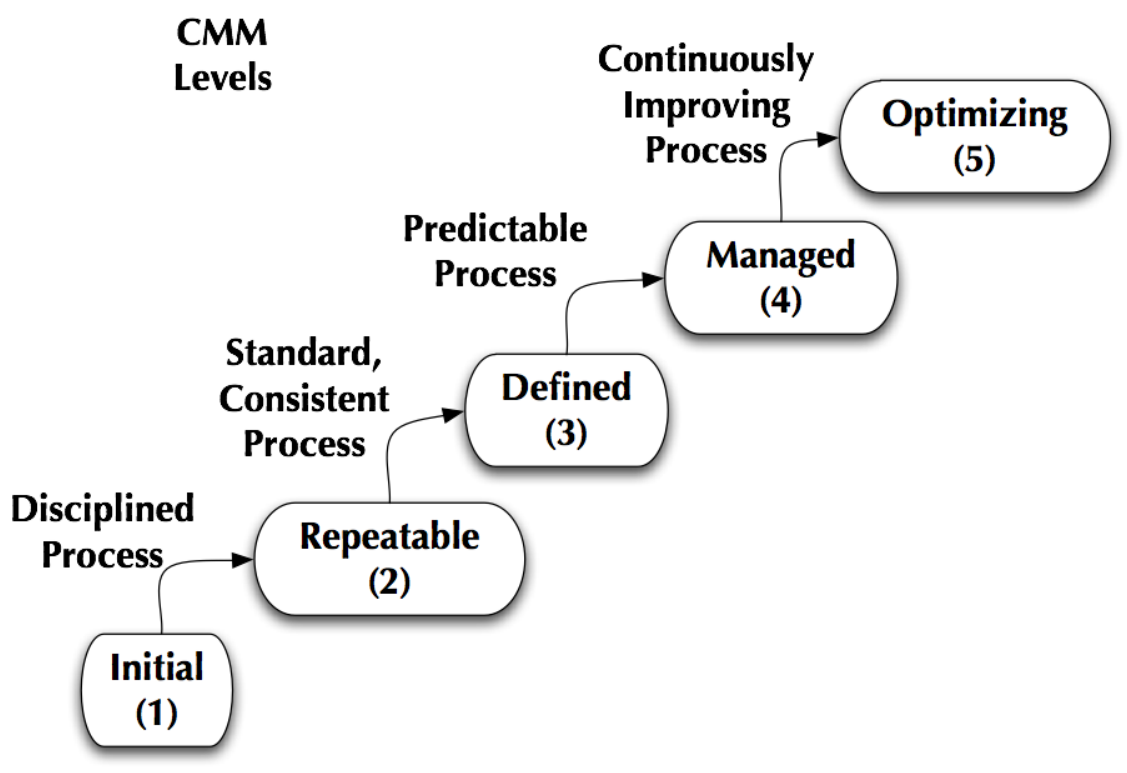

Gambar 2. Tingkatan level pada CMM

Berdasarkan tingkatan level pada Gambar 2, tiap level memiliki penjelasan sebagai:

Level 1 (Initial)

Pada level ini, segala sesuatu dalam proses bisnis masih dilakukan bersifat sementara dan belum terencana. Pada level ini juga belum ada dokumentasi pada setiap kegiatan yang ada di lingkungan sekolah. 


\section{Level 2 (Repeatable)}

Pada level ini, pengembangan proses bisnis telah terdefinisi dan telah terdokumentasi, namun belum terstandarisasi dengan baik.

Level 3 (Defined)

Pada level ini, pengembangan proses bisnis telah konsisten dan terdefinisi sehingga semua orang yang terlibat di dalamnya dapat memahami dan menerapkannya.

Level 4 (Managed)

Pada level ini, pengembangan proses bisnis terukur secara kuantitatif, dan semua proses selalu dievaluasi berdasarkan hasil analisis data yang dikumpulkan.

\section{Level 5 (Optimizing)}

Pada level ini, pengembangan proses bisnis secara terus menerus dilakukan optimalisasi. Sekolah dapat merubah prosedur suatu proses apabila ditemukan prosedur baru yang dianggap lebih baik dari prosedur sebelumnya.

Pada lima tingkatan level CMM, masing-masing level memiliki kunci proses area. kunci proses area tersebut digunakan sebagai syarat tercapainya pada salah satu level [5]. Agar suatu tingkatan level CMM dinyatakan valid, maka pemenuhannya harus dimulai dari level yang paling kecil lalu berangsur ke level yang lebih besar tanpa melewatkan satupun kunci proses area yang ada di level yang lebih kecil. Berikut penjelasan mengenai kunci area proses yang ada di setiap levelnya :

Kunci proses area level 1 (Initial)

1. Belum Terencana. Proses yang dilakukan belum terencana artinya penyusunan rencana proses bisnis belum memiliki arah yang jelas untuk mencapai tujuan yang diinginkan.

2. Bersifat Sementara dan Khusus. Pada kunci proses area ini, pembentukan panitia dalam suatu kegiatan proses bisnis dibentuk dalam jangka waktu tertentu dan bekerja dengan mandiri tanpa bantuan panitia lain.

3. Belum Terdokumentasi. Proses yang dilakukan belum terdokumentasi artinya belum adanya catatan resmi atau hasil dokumentasi berupa foto maupun video.

Kunci proses area level 2 (Repeatable)

1. Telah Terdefinisi. Proses yang dilakukan telah terdefinisi artinya rencana proses bisnis telah memiliki arah dan tujuan yang jelas.

2. Terdokumentasi. Pada kunci proses area ini, segala kegiatan proses bisnis telah dicatat dan terdokumentasi dalam bentuk foto maupun video.

3. Belum Terstandarisasi. Proses belum terstandarisasi artinya belum adanya penentuan pedoman standar yang ditetapkan dalam kegiatan proses bisnis.

Kunci proses area level 3 (Defined)

1. Telah Konsisten. Pada kunci proses area ini, telah dibentuknya penentuan pedoman standar dalam kegiatan proses bisnis sehingga dapat memudahkan pekerjaan yang ada.

2. Dapat Dipahami dan Diterapkan. Proses dapat dipahami dan diterapkan artinya segala kegiatan proses bisnis dapat dipahami dan dilakukan dengan maksimal karena telah dibentuk pedoman standar sebelumnya. 
Kunci proses area level 4 (Managed)

1. Terukur Secara Kuantitatif. Pada kunci proses area ini, segala kegiatan proses bisnis dilakukan secara sistematis, terencana, dan terstruktur dengan jelas.

2. Analisis dan Evaluasi. Pada kunci proses area ini, segala kegiatan proses bisnis akan dianalisis kekurangan dan kelebihannya serta dievaluasi agar kegiatan proses bisnis dapat berjalan dengan baik.

Kunci proses area level 5 (Optimizing)

1. Optimalisasi. Pada kunci proses area ini, dilakukan pencarian solusi terbaik dan mengoptimalkan segala sesuatu yang sudah ada untuk mendapatkan hasil yang ideal atau optimal.

2. Memperbarui. Pada kunci proses area ini, dilakukan pembaharuan terhadap prosedur proses bisnis yang dianggap harus diubah atau dilakukan perbaikan untuk mendapatkan hasil yang sesuai dengan tujuan.

\section{Requirement Analysis}

Setelah melakukan analisis ERP berdasarkan level tingkat kematangan pada CMM, selanjutnya adalah melakukan analisis kebutuhan untuk merancang sebuah sistem informasi di sekolah. Adapun bagian dari sistem informasi, dan bagian ini digambarkan seperti piramida pada gambar 3 .

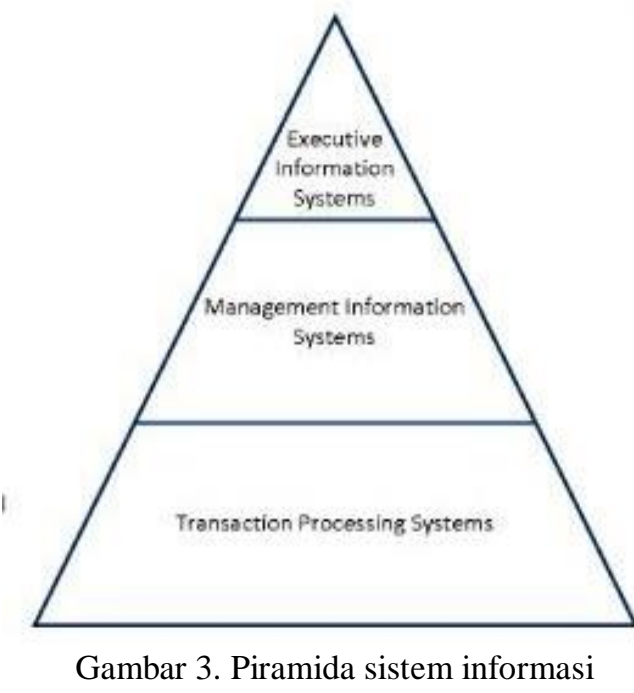

Analisis kebutuhan dalam sistem informasi akan dianalisis berdasarkan piramida sistem informasi pada Gambar 3. Penjelasan serta analisis kebutuhan dari piramida sistem pada gambar 3 berdasarkan tingkatan level CMM adalah sebagai berikut :

1. Executive information system. merupakan sistem untuk mendukung keputusan yang membantu eksekutif tingkat atas dalam menganalisis dan membandingkan informasi yang penting sehingga bisa memonitoring dan mengidentifikasi peluang serta masalah[6]. Analisis kebutuhan pada sistem informasi bagian Executive information system berdasarkan tingkatan level CMM dijelaskan pada Tabel 1 dibawah ini: 
Tabel 1. Analisis kebutuhan pada sistem informasi bagian execute information system berdasarkan tingkatan level CMM

\begin{tabular}{|c|c|c|c|c|}
\hline Level & Proses & Personil & Peralatan & $\begin{array}{l}\text { Data yang } \\
\text { dibutuhkan }\end{array}$ \\
\hline 1 & Rekap data guru dan siswa & $\begin{array}{l}\text { Pihak tata usaha } \\
\text { sekolah dan kepala } \\
\text { sekolah }\end{array}$ & Alat tulis & Data guru dan siswa \\
\hline 2 & $\begin{array}{l}\text { Rekap data guru dan siswa, } \\
\text { rekap data akreditasi sekolah }\end{array}$ & $\begin{array}{l}\text { Pihak tata usaha } \\
\text { sekolah dan kepala } \\
\text { sekolah }\end{array}$ & Alat tulis & $\begin{array}{l}\text { Data guru dan siswa, } \\
\text { data hasil akreditasi } \\
\text { sekolah }\end{array}$ \\
\hline 3 & $\begin{array}{l}\text { Rekap data guru dan siswa, } \\
\text { rekap data akreditasi } \\
\text { sekolah, rekap data } \\
\text { infrastruktur sekolah, rekap } \\
\text { data prestasi sekolah }\end{array}$ & $\begin{array}{l}\text { Pihak tata usaha } \\
\text { sekolah, guru, dan } \\
\text { kepala sekolah }\end{array}$ & Alat tulis & $\begin{array}{l}\text { Data guru dan siswa, } \\
\text { data hasil akreditasi } \\
\text { sekolah, data } \\
\text { infrastruktur } \\
\text { sekolah, data } \\
\text { prestasi sekolah }\end{array}$ \\
\hline 4 & $\begin{array}{l}\text { Rekap data guru dan siswa, } \\
\text { rekap data akreditasi } \\
\text { sekolah, rekap data } \\
\text { infrastruktur sekolah, rekap } \\
\text { data prestasi sekolah, } \\
\text { proposal kegiatan yang ada } \\
\text { di lingkungan sekolah, } \\
\text { laporan kegiatan yang } \\
\text { diadakan di sekolah }\end{array}$ & $\begin{array}{l}\text { Pihak tata usaha } \\
\text { sekolah, guru, } \\
\text { kepala sekolah dan } \\
\text { pihak organisasi }\end{array}$ & Alat tulis & $\begin{array}{l}\text { Data guru dan siswa, } \\
\text { data hasil akreditasi } \\
\text { sekolah, data } \\
\text { infrastruktur } \\
\text { sekolah, data } \\
\text { prestasi sekolah, } \\
\text { data kegiatan } \\
\text { organisasi di sekolah }\end{array}$ \\
\hline 5 & $\begin{array}{l}\text { Rekap data guru dan siswa, } \\
\text { rekap data infrastruktur } \\
\text { sekolah, laporan kegiatan } \\
\text { yang diadakan di sekolah }\end{array}$ & $\begin{array}{l}\text { Pihak tata usaha } \\
\text { sekolah, guru, } \\
\text { kepala sekolah dan } \\
\text { pihak organisasi }\end{array}$ & Alat tulis & $\begin{array}{l}\text { Data guru dan siswa, } \\
\text { data infrastruktur } \\
\text { sekolah, data } \\
\text { kegiatan organisasi } \\
\text { di sekolah }\end{array}$ \\
\hline
\end{tabular}

2. Management information system. Management information system adalah sebuah metode formal untuk menyediakan informasi yang akurat dan tepat waktu bagi manajemen yang diperlukan untuk mempermudah proses pengambilan keputusan, dan memungkinkan fungsi-fungsi dari manajemen seperti perencanaan, pengendalian, dan operasional dapat dilakukan secara efektif[7]. Analisis kebutuhan pada sistem informasi bagian Management information system berdasarkan tingkatan level CMM dijelaskan pada tabel 2 dibawah ini :

Tabel 2. Analisis kebutuhan pada sistem informasi bagian management information system berdasarkan tingkatan level CMM

\begin{tabular}{|l|l|l|l|l|}
\hline Level & \multicolumn{1}{|c|}{ Proses } & Personil & \multicolumn{1}{c|}{ Peralatan } & \multicolumn{1}{c|}{$\begin{array}{c}\text { Data yang } \\
\text { dibutuhkan }\end{array}$} \\
\hline 1 & $\begin{array}{l}\text { Penerimaan siswa baru, } \\
\text { pengadaan sarana dan } \\
\text { prasarana, penjadwalan } \\
\text { kegiatan belajar mengajar }\end{array}$ & $\begin{array}{l}\text { Pihak tata usaha } \\
\text { sekolah dan guru }\end{array}$ & Alat tulis & $\begin{array}{l}\text { Data pendaftaran } \\
\text { siswa baru, data } \\
\text { sarana prasarana, data } \\
\text { jadwal pembelajaran }\end{array}$ \\
\hline 2 & $\begin{array}{l}\text { Penerimaan siswa baru, } \\
\text { pengadaan sarana dan }\end{array}$ & $\begin{array}{l}\text { Pihak tata usaha } \\
\text { sekolah, guru dan }\end{array}$ & Alat tulis & $\begin{array}{l}\text { Data pendaftaran } \\
\text { siswa baru, data }\end{array}$ \\
\hline
\end{tabular}




\begin{tabular}{|c|c|c|c|c|}
\hline & $\begin{array}{l}\text { prasarana, penjadwalan } \\
\text { kegiatan belajar mengajar, } \\
\text { pengelolaan kurikulum }\end{array}$ & kepala sekolah & & $\begin{array}{l}\text { sarana prasarana, data } \\
\text { jadwal pembelajaran, } \\
\text { data kurikulum }\end{array}$ \\
\hline 3 & $\begin{array}{l}\text { Penerimaan siswa baru, } \\
\text { pengadaan sarana dan } \\
\text { prasarana, penjadwalan } \\
\text { kegiatan belajar mengajar, } \\
\text { pengelolaan kurikulum, } \\
\text { pengadaan sarana dan } \\
\text { prasarana, pengelolaan } \\
\text { perpustakaan }\end{array}$ & $\begin{array}{l}\text { Pihak tata usaha } \\
\text { sekolah, guru, } \\
\text { kepala sekolah dan } \\
\text { pustakawan }\end{array}$ & Alat tulis & $\begin{array}{l}\text { Data pendaftaran } \\
\text { siswa baru, data } \\
\text { sarana prasarana, data } \\
\text { jadwal pembelajaran, } \\
\text { data kurikulum, data } \\
\text { sarana dan prasarana, } \\
\text { data perpustakaan }\end{array}$ \\
\hline 4 & $\begin{array}{l}\text { Penerimaan siswa baru, } \\
\text { pengadaan sarana dan } \\
\text { prasarana, penjadwalan } \\
\text { kegiatan belajar mengajar, } \\
\text { pengelolaan kurikulum, } \\
\text { pengadaan sarana dan } \\
\text { prasarana, pengelolaan } \\
\text { perpustakaan, manajemen } \\
\text { organisasi sekolah, } \\
\text { manajemen kegiatan luar } \\
\text { sekolah }\end{array}$ & $\begin{array}{l}\text { Pihak tata usaha } \\
\text { sekolah, guru, } \\
\text { kepala sekolah, } \\
\text { pustakawan dan } \\
\text { pihak organisasi }\end{array}$ & Alat tulis & $\begin{array}{l}\text { Data pendaftaran } \\
\text { siswa baru, data } \\
\text { sarana prasarana, data } \\
\text { jadwal pembelajaran, } \\
\text { data kurikulum, data } \\
\text { sarana dan prasarana, } \\
\text { data perpustakaan, } \\
\text { data organisasi }\end{array}$ \\
\hline 5 & $\begin{array}{l}\text { Penerimaan siswa baru, } \\
\text { penjadwalan kegiatan } \\
\text { belajar mengajar, } \\
\text { pengelolaan kurikulum, } \\
\text { manajemen organisasi } \\
\text { sekolah }\end{array}$ & $\begin{array}{l}\text { Pihak tata usaha } \\
\text { sekolah, guru, } \\
\text { kepala sekolah dan } \\
\text { pihak organisasi }\end{array}$ & Alat tulis & $\begin{array}{l}\text { Data pendaftaran } \\
\text { siswa baru, data } \\
\text { jadwal pembelajaran, } \\
\text { data kurikulum, data } \\
\text { organisasi }\end{array}$ \\
\hline
\end{tabular}

3. Transaction processing system. Transaction processing system adalah sistem informasi terkomputerisasi yang dikembangkan untuk memproses sejumlah besar data transaksi bisnis rutin untuk menghasilkan informasi keuangan[8]. Analisis kebutuhan pada sistem informasi bagian Transaction processing system berdasarkan tingkatan level CMM dijelaskan pada Tabel 3 dibawah ini :

Tabel 3. Analisis kebutuhan pada sistem informasi bagian transaction information system berdasarkan tingkatan level CMM

\begin{tabular}{|l|l|l|l|l|}
\hline Level & \multicolumn{1}{|c|}{ Proses } & \multicolumn{1}{|c|}{ Personil } & \multicolumn{1}{c|}{ Peralatan } & Data yang dibutuhkan \\
\hline 1 & $\begin{array}{l}\text { Pembelian buku lembar } \\
\text { kerja siswa }\end{array}$ & $\begin{array}{l}\text { Pihak tata usaha } \\
\text { sekolah }\end{array}$ & $\begin{array}{l}\text { Kwitansi, alat } \\
\text { tulis }\end{array}$ & $\begin{array}{l}\text { Data buku lembar } \\
\text { kerja siswa }\end{array}$ \\
\hline 2 & $\begin{array}{l}\text { Pembelian buku lembar } \\
\text { kerja siswa, administrasi } \\
\text { pembayaran SPP }\end{array}$ & $\begin{array}{l}\text { Pihak tata usaha } \\
\text { sekolah }\end{array}$ & $\begin{array}{l}\text { Kwitansi, alat } \\
\text { tulis }\end{array}$ & $\begin{array}{l}\text { Data buku lembar } \\
\text { kerja siswa, data } \\
\text { pembayaran SPP }\end{array}$ \\
\hline 3 & $\begin{array}{l}\text { Pembelian buku lembar } \\
\text { kerja siswa, administrasi } \\
\text { pembayaran SPP, transaksi } \\
\text { penerimaan dan pengeluaran } \\
\text { kas sekolah, transaksi biaya } \\
\text { pengembangan infrastruktur } \\
\text { sekolah }\end{array}$ & $\begin{array}{l}\text { Pihak tata usaha } \\
\text { sekolah dan kepala } \\
\text { sekolah }\end{array}$ & $\begin{array}{l}\text { Kwitansi, alat } \\
\text { tulis }\end{array}$ & $\begin{array}{l}\text { Data buku lembar } \\
\text { kerja siswa, data } \\
\text { pembayaran SPP, data } \\
\text { penerimaan dan } \\
\text { pengeluaran kas } \\
\text { sekolah, data } \\
\text { pengembangan } \\
\text { infrastruktur sekolah }\end{array}$ \\
\hline
\end{tabular}




\begin{tabular}{|l|l|l|l|l|}
\hline 4 & $\begin{array}{l}\text { Pembelian buku lembar } \\
\text { kerja siswa, administrasi } \\
\text { pembayaran SPP, transaksi } \\
\text { penerimaan dan pengeluaran } \\
\text { kas sekolah, transaksi biaya } \\
\text { pengembangan infrastruktur } \\
\text { sekolah, transaksi } \\
\text { pembiayaan kegiatan } \\
\text { organisasi }\end{array}$ & $\begin{array}{l}\text { Pihak tata usaha } \\
\text { sekolah, kepala } \\
\text { sekolah dan pihak } \\
\text { organisasi }\end{array}$ & $\begin{array}{l}\text { Kwitansi, alat } \\
\text { tulis }\end{array}$ & $\begin{array}{l}\text { Data buku lembar } \\
\text { kerja siswa, data } \\
\text { pembayaran SPP, data } \\
\text { penerimaan dan } \\
\text { pengeluaran kas } \\
\text { sekolah, data } \\
\text { pengembangan } \\
\text { infrastruktur sekolah, } \\
\text { data pembiayaan } \\
\text { kegiatan organisasi }\end{array}$ \\
\hline 5 & $\begin{array}{l}\text { Pembayaran biaya sekolah } \\
\text { satu semester, transaksi } \\
\text { penerimaan dan pengeluaran } \\
\text { kas sekolah }\end{array}$ & $\begin{array}{l}\text { Pihak tata usaha } \\
\text { sekolah dan kepala } \\
\text { sekolah }\end{array}$ & $\begin{array}{l}\text { Kwitansi, alat } \\
\text { tulis }\end{array}$ & $\begin{array}{l}\text { Data pembayaran } \\
\text { biaya sekolah satu } \\
\text { semester, data } \\
\text { penerimaan dan } \\
\text { pengeluaran kas } \\
\text { sekolah }\end{array}$ \\
\hline
\end{tabular}

\section{Logical Design}

Setelah melakukan analisis kebutuhan pada sistem informasi, maka kebutuhan yang dianalisis tadi diubah menjadi rancangan ERP sekolah berdasarkan CMM. Berikut ini adalah rancangan ERP sekolah berdasarkan CMM :

\section{Arsitektur ERP sekolah berdasarkan CMM level 1}

- Executive information system

Di dalam executive information system level 1 terdapat proses-proses diantaranya adalah proses rekap data guru dan siswa. Dalam proses ini kepala sekolah akan langsung meminta rekap data guru dan siswa kepada pihak tata usaha sekolah. Setelah mengetahui proses-proses diatas, maka di dalam executive information system level 1 terdapat fitur tampilan data guru dan siswa. Dalam fitur ini akan menampilkan data-data guru dan siswa yang direkap oleh pihak tata usaha sekolah, sehingga kepala sekolah bisa langsung mendapatkan data siswa secara real time.

\section{- Management information system}

Di dalam management information system level 1 terdapat proses-proses diantaranya sebagai berikut:

1. Proses penerimaan peserta didik baru. Dalam proses ini peserta didik baru diminta untuk mengisi data diri dan melakukan pendaftaran pada sebuah formulir.

2. Proses pengelolaan data sarana dan prasarana. Dalam proses ini pihak tata usaha sekolah akan mendata sarana dan prasarana yang di sekolah.

3. Proses penjadwalan kegiatan belajar mengajar. Dalam proses ini pihak kurikulum sekolah akan mengatur jadwal kegiatan belajar mengajar.

Setelah mengetahui proses-proses diatas, maka di dalam management information system level 1 terdapat fitur-fitur sebagai berikut :

1. Fitur penerimaan siswa baru. Dalam fitur ini akan ada tahap-tahap dalam pendaftaran peserta didik baru .

2. Fitur pengelolaan data sarana dan prasarana. Dalam fitur ini pihak tata usaha sekolah menampilkan data sarana dan prasarana yang ada di sekolah .

3. Fitur penjadwalan kegiatan belajar mengajar. Dalam fitur ini akan ada penjadwalan yang dilakukan oleh pihak kurikulum sekolah. 
- Transaction processing system

Di dalam transaction information system level 1 terdapat proses-proses diantaranya sebagai berikut :

1. Proses pembelian buku lembar kerja siswa. Dalam proses ini guru atau tenaga didik akan membeli lembar kerja siswa untuk kegiatan belajar mengajar. Setelah mengetahui proses-proses diatas, maka di dalam transaction information system level 1 terdapat fitur-fitur sebagai berikut :

1. Fitur pembelian buku lembar kerja siswa

Dalam fitur ini tersedia layanan pembelian buku lembar kerja siswa.

2. Arsitektur ERP sekolah berdasarkan CMM level 2

- Executive information system

Di dalam executive information system level 2 terdapat proses-proses diantaranya sebagai berikut :

1. Proses rekap data guru dan siswa. Dalam proses ini kepala sekolah akan langsung meminta rekap data guru dan siswa kepada pihak tata usaha sekolah.

2. Proses data akreditasi sekolah. Dalam proses ini kepala sekolah atau wakilnya akan meminta data akreditasi sekolah kepada pihak tata usaha sekolah.

Setelah mengetahui proses-proses diatas, maka di dalam executive information system level 2 terdapat fitur-fitur sebagai berikut :

1. Fitur tampilan data guru dan siswa. Dalam fitur ini akan menampilkan data-data guru dan siswa yang direkap oleh pihak tata usaha sekolah, sehingga kepala sekolah bisa langsung mendapatkan data siswa secara real time.

2. Fitur tampilan data akreditasi sekolah. Dalam fitur ini akan ditampilkan data-data terkait akreditasi sekolah oleh bagian tata usaha untuk dapat dilihat langsung oleh kepala sekolah atau wakilnya.

- Management Information system

Di dalam management information system level 2 terdapat proses-proses diantaranya sebagai berikut:

1. Proses penerimaan peserta didik baru. Dalam proses ini peserta didik baru diminta untuk mengisi data diri dan melakukan pendaftaran pada sebuah formulir.

2. Proses pengelolaan data sarana dan prasarana. Dalam proses ini pihak tata usaha sekolah akan mendata sarana dan prasarana yang di sekolah.

3. Proses penjadwalan kegiatan belajar mengajar. Dalam proses ini pihak kurikulum sekolah akan mengatur jadwal kegiatan belajar mengajar.

4. Proses pengelolaan kurikulum. Dalam proses ini pihak wakil kepala sekolah bagian kurikulum akan membuat susunan kurikulum agar kegiatan belajar mengajar dapat terarah.

Setelah mengetahui proses-proses diatas, maka di dalam management information system level 2 terdapat fitur-fitur sebagai berikut :

1. Fitur penerimaan siswa baru. Dalam fitur ini akan ada tahap-tahap dalam pendaftaran peserta didik baru .

2. Fitur pengelolaan data sarana dan prasarana. Dalam fitur ini pihak tata usaha sekolah menampilkan data sarana dan prasarana yang ada di sekolah .

3. Fitur penjadwalan kegiatan belajar mengajar. Dalam fitur ini akan ada penjadwalan yang dilakukan oleh pihak kurikulum sekolah.

4. Fitur pengelolaan kurikulum 
Dalam fitur ini pihak wakil kepala sekolah bagian kurikulum dapat menyusun kurikulum yang tepat untuk kelancaran kegiatan belajar mengajar.

- Transaction processing system

Di dalam transaction information system level 2 terdapat proses-proses diantaranya sebagai berikut :

1. Proses pembelian buku lembar kerja siswa. Dalam proses ini guru atau tenaga didik akan membeli lembar kerja siswa untuk kegiatan belajar mengajar.

2. Proses administrasi pembayaran SPP. Dalam proses ini siswa akan diminta untuk membayar biaya Sumbangan Pembinaan Pendidikan (SPP) kepada bagian tata usaha.

Setelah mengetahui proses-proses diatas, maka di dalam transaction information system level 2 terdapat fitur-fitur sebagai berikut :

1. Fitur pembelian buku lembar kerja siswa. Dalam fitur ini tersedia layanan pembelian buku lembar kerja siswa.

2. Fitur pembayaran SPP. Dalam fitur ini bagian tata usaha akan menampilkan data siswa yang sudah membayar SPP.

3. Arsitektur ERP sekolah berdasarkan CMM level 3

- Executive information system

Di dalam executive information system level 3 terdapat proses-proses diantaranya sebagai berikut :

1. Proses rekap data guru dan siswa. Dalam proses ini kepala sekolah akan langsung meminta rekap data guru dan siswa kepada pihak tata usaha sekolah.

2. Proses data akreditasi sekolah. Dalam proses ini wakil kepala sekolah melakukan pendataan terkait akreditasi sekolah.

3. Proses rekap data infrastruktur sekolah. Dalam proses ini wakil kepala sekolah bidang sarana dan prasarana akan meminta rekap data infrastruktur sekolah kepada pihak tata usaha.

4. Proses rekap data prestasi sekolah. Dalam proses ini pihak sekolah bidang kesiswaan akan melakukan rekap data prestasi yang telah diraih sekolah.

Setelah mengetahui proses-proses diatas, maka di dalam executive information system level 3 terdapat fitur-fitur sebagai berikut :

1. Fitur tampilan data guru dan siswa. Dalam fitur ini akan menampilkan data-data guru dan siswa yang direkap oleh pihak tata usaha sekolah, sehingga kepala sekolah bisa langsung mendapatkan data siswa secara real time.

2. Fitur tampilan data akreditasi sekolah. Dalam fitur ini akan ditampilkan data-data terkait akreditasi sekolah oleh bagian tata usaha untuk dapat dilihat langsung oleh kepala sekolah atau wakilnya.

3. Fitur tampilan data infrastruktur sekolah. Dalam fitur ini akan ditampilkan datadata infrastruktur sekolah oleh pihak tata usaha, sehingga wakil kepala sekolah bidang sarana dan prasarana bisa mendapatkan datanya secara langsung.

4. Fitur tampilan data prestasi sekolah. Dalam fitur ini akan ditampilkan data prestasi sekolah yang telah dicapai oleh pihak sekolah bagian kesiswaan.

- Management Information system

Di dalam management information system level 3 terdapat proses-proses diantaranya sebagai berikut : 
1. Proses penerimaan peserta didik baru. Dalam proses ini peserta didik baru diminta untuk mengisi data diri dan melakukan pendaftaran pada sebuah formulir.

2. Proses pengelolaan data sarana dan prasarana. Dalam proses ini pihak tata usaha sekolah akan mendata sarana dan prasarana yang di sekolah.

3. Proses penjadwalan kegiatan belajar mengajar. Dalam proses ini pihak kurikulum sekolah akan mengatur jadwal kegiatan belajar mengajar.

4. Proses pengelolaan kurikulum. Dalam proses ini pihak wakil kepala sekolah bagian kurikulum akan membuat susunan kurikulum agar kegiatan belajar mengajar dapat terarah.

5. Proses pengelolaan perpustakaan. Dalam proses ini petugas perpustakaan akan melakukan pengelolaan data perpustakaan.

Setelah mengetahui proses-proses diatas, maka di dalam management information system level 3 terdapat fitur-fitur sebagai berikut :

1. Fitur penerimaan siswa baru. Dalam fitur ini akan ada tahap-tahap dalam pendaftaran peserta didik baru .

2. Fitur pengelolaan data sarana dan prasarana. Dalam fitur ini pihak tata usaha sekolah menampilkan data sarana dan prasarana yang ada di sekolah .

3. Fitur penjadwalan kegiatan belajar mengajar. Dalam fitur ini akan ada penjadwalan yang dilakukan oleh pihak kurikulum sekolah.

4. Fitur pengelolaan kurikulum. Dalam fitur ini pihak wakil kepala sekolah bagian kurikulum dapat menyusun kurikulum yang tepat untuk kelancaran kegiatan belajar mengajar.

5. Fitur pengelolaan perpustakaan. Dalam fitur ini petugas perpustakaan akan menampilkan data perpustakaan.

\section{- Transaction processing system}

Di dalam transaction information system level 3 terdapat proses-proses diantaranya sebagai berikut :

1. Proses pembelian buku lembar kerja siswa. Dalam proses ini guru atau tenaga didik akan membeli lembar kerja siswa untuk kegiatan belajar mengajar.

2. Proses administrasi pembayaran SPP. Dalam proses ini siswa akan diminta untuk membayar biaya Sumbangan Pembinaan Pendidikan (SPP) kepada bagian tata usaha.

3. Proses transaksi penerimaan dan pengeluaran kas. Dalam proses ini bagian tata usaha akan mencatat semua penerimaan dan pengeluaran kas sekolah.

4. Proses transaksi biaya pengembangan infrastruktur sekolah. Dalam proses ini bagian tata usaha akan mencatat dan mendata biaya yang digunakan dalam pengembangan infrastruktur sekolah.

Setelah mengetahui proses-proses diatas, maka di dalam transaction information system level 3 terdapat fitur-fitur sebagai berikut :

1. Fitur pembelian buku lembar kerja siswa. Dalam fitur ini tersedia layanan pembelian buku lembar kerja siswa.

2. Fitur pembayaran SPP. Dalam fitur ini bagian tata usaha akan menampilkan data siswa yang sudah membayar SPP.

3. Fitur transaksi kas. Dalam fitur ini bagian tata usaha akan menampilkan dan mendata penerimaan dan pengeluaran kas sekolah. 
4. Fitur transaksi pengembangan infrastruktur. Dalam fitur ini bagian tata usaha akan menampilkan data biaya yang dikeluarkan untuk pengembangan infrastruktur sekolah.

4. Arsitektur ERP sekolah berdasarkan CMM level 4

- Executive information system

Di dalam executive information system level 4 terdapat proses-proses diantaranya sebagai berikut :

1. Proses rekap data guru dan siswa. Dalam proses ini kepala sekolah akan langsung meminta rekap data guru dan siswa kepada pihak tata usaha sekolah.

2. Proses data akreditasi sekolah. Dalam proses ini wakil kepala sekolah melakukan pendataan terkait akreditasi sekolah.

3. Proses rekap data infrastruktur sekolah. Dalam proses ini wakil kepala sekolah bidang sarana dan prasarana akan meminta rekap data infrastruktur sekolah kepada pihak tata usaha.

4. Proses rekap data prestasi sekolah. Dalam proses ini pihak sekolah bidang kesiswaan akan melakukan rekap data prestasi yang telah diraih sekolah.

5. Proses proposal kegiatan yang ada di lingkungan sekolah. Dalam proses ini kepala sekolah akan melakukan pengecekan terhadap proposal yang diajukan.

6. Proses laporan kegiatan yang diadakan di lingkungan sekolah. Dalam proses ini kepala sekolah akan meninjau hasil pelaksanaan kegiatan yang telah diadakan.

Setelah mengetahui proses-proses diatas, maka di dalam executive information system level 4 terdapat fitur-fitur sebagai berikut :

1. Fitur tampilan data guru dan siswa. Dalam fitur ini akan menampilkan data-data guru dan siswa yang direkap oleh pihak tata usaha sekolah, sehingga kepala sekolah bisa langsung mendapatkan data siswa secara real time.

2. Fitur tampilan data akreditasi sekolah. Dalam fitur ini akan ditampilkan data-data terkait akreditasi sekolah oleh bagian tata usaha untuk dapat dilihat langsung oleh kepala sekolah atau wakilnya.

3. Fitur tampilan data infrastruktur sekolah. Dalam fitur ini akan ditampilkan datadata infrastruktur sekolah oleh pihak tata usaha, sehingga wakil kepala sekolah bidang sarana dan prasarana bisa mendapatkan datanya secara langsung.

4. Fitur tampilan data prestasi sekolah. Dalam fitur ini akan ditampilkan data prestasi sekolah yang telah dicapai oleh pihak sekolah bagian kesiswaan.

5. Fitur tampilan proposal kegiatan. Dalam fitur ini akan ditampilkan data-data yang ada di dalam proposal untuk dilakukan pengecekan oleh kepala sekolah.

6. Fitur tampilan laporan kegiatan. Dalam fitur ini akan ditampilkan data berupa hasil kegiatan yang telah dilakukan kepada kepala sekolah.

\section{- Management Information system}

Di dalam management information system level 4 terdapat proses-proses diantaranya sebagai berikut :

1. Proses penerimaan peserta didik baru. Dalam proses ini peserta didik baru diminta untuk mengisi data diri dan melakukan pendaftaran pada sebuah formulir.

2. Proses pengelolaan data sarana dan prasarana. Dalam proses ini pihak tata usaha sekolah akan mendata sarana dan prasarana yang di sekolah. 
3. Proses penjadwalan kegiatan belajar mengajar. Dalam proses ini pihak kurikulum sekolah akan mengatur jadwal kegiatan belajar mengajar.

4. Proses pengelolaan kurikulum. Dalam proses ini pihak wakil kepala sekolah bagian kurikulum akan membuat susunan kurikulum agar kegiatan belajar mengajar dapat terarah.

5. Proses pengelolaan perpustakaan. Dalam proses ini petugas perpustakaan akan melakukan pengelolaan data perpustakaan.

6. Proses manajemen organisasi sekolah. Dalam proses ini tata usaha dan pihak sekolah bagian kesiswaan akan bekerja sama mengatur kegiatan organisasi yang ada di sekolah.

7. Proses manajemen kegiatan luar sekolah. Dalam proses ini tata usaha dan pihak sekolah bagian kesiswaan akan bekerja sama mengatur kegiatan di luar sekolah.

Setelah mengetahui proses-proses diatas, maka di dalam management information system level 4 terdapat fitur-fitur sebagai berikut:

1. Fitur penerimaan siswa baru. Dalam fitur ini akan ada tahap-tahap dalam pendaftaran peserta didik baru .

2. Fitur pengelolaan data sarana dan prasarana. Dalam fitur ini pihak tata usaha sekolah menampilkan data sarana dan prasarana yang ada di sekolah .

3. Fitur penjadwalan kegiatan belajar mengajar. Dalam fitur ini akan ada penjadwalan yang dilakukan oleh pihak kurikulum sekolah.

4. Fitur pengelolaan kurikulum. Dalam fitur ini pihak wakil kepala sekolah bagian kurikulum dapat menyusun kurikulum yang tepat untuk kelancaran kegiatan belajar mengajar.

5. Fitur pengelolaan perpustakaan. Dalam fitur ini petugas perpustakaan akan menampilkan data perpustakaan.

6. Fitur manajemen organisasi sekolah. Dalam fitur ini akan ditampilkan kegiatan organisasi yang ada di dalam sekolah.

7. Fitur manajemen kegiatan luar sekolah. Dalam fitur ni akan ditampilkan kegiatan di luar lingkungan sekolah.

- Transaction processing system

Di dalam transaction information system level 4 terdapat proses-proses diantaranya sebagai berikut :

1. Proses pembelian buku lembar kerja siswa. Dalam proses ini guru atau tenaga didik akan membeli lembar kerja siswa untuk kegiatan belajar mengajar.

2. Proses administrasi pembayaran SPP. Dalam proses ini siswa akan diminta untuk membayar biaya Sumbangan Pembinaan Pendidikan (SPP) kepada bagian tata usaha.

3. Proses transaksi penerimaan dan pengeluaran kas. Dalam proses ini bagian tata usaha akan mencatat semua penerimaan dan pengeluaran kas sekolah.

4. Proses transaksi biaya pengembangan infrastruktur sekolah. Dalam proses ini bagian tata usaha akan mencatat dan mendata biaya yang digunakan dalam pengembangan infrastruktur sekolah.

5. Proses transaksi pembiayaan kegiatan organisasi. Dalam proses ini bagian tata usaha akan mencatat segala pengeluaran untuk kegiatan organisasi sekolah.

Setelah mengetahui proses-proses diatas, maka di dalam transaction information system level 4 terdapat fitur-fitur sebagai berikut : 
1. Fitur pembelian buku lembar kerja siswa. Dalam fitur ini tersedia layanan pembelian buku lembar kerja siswa.

2. Fitur pembayaran SPP. Dalam fitur ini bagian tata usaha akan menampilkan data siswa yang sudah membayar SPP.

3. Fitur transaksi kas. Dalam fitur ini bagian tata usaha akan menampilkan dan mendata penerimaan dan pengeluaran kas sekolah.

4. Fitur pengembangan infrastruktur. Dalam fitur ini bagian tata usaha akan menampilkan data biaya yang dikeluarkan untuk pengembangan infrastruktur sekolah.

5. Fitur transaksi kegiatan organisasi. Dalam fitur ini bagian tata usaha akan menampilkan data keuangan yang dikeluarkan untuk kegiatan organisasi.

5. Arsitektur ERP sekolah berdasarkan CMM level 5

- Executive information system

Di dalam executive information system level 5 terdapat proses-proses diantaranya sebagai berikut :

1. Proses rekap data guru dan siswa. Dalam proses ini kepala sekolah akan langsung meminta rekap data guru dan siswa kepada pihak tata usaha sekolah yang telah disimpan di dalam database komputer sebelumnya.

2. Proses laporan kegiatan yang diadakan di lingkungan sekolah. Dalam proses ini kepala sekolah akan meninjau hasil pelaksanaan kegiatan yang telah diadakan di lingkungan sekolah .

3. Proses rekap data infrastruktur sekolah. Dalam proses ini wakil kepala sekolah bidang sarana dan prasarana akan meminta rekap data infrastruktur sekolah kepada pihak tata usaha telah disimpan di dalam database komputer sebelumnya..

Setelah mengetahui proses-proses diatas, maka di dalam executive information system level 5 terdapat fitur-fitur sebagai berikut :

1. Fitur tampilan data guru dan siswa. Dalam fitur ini akan menampilkan data-data guru dan siswa yang direkap oleh pihak tata usaha sekolah, sehingga dapat diserahkan langsung kepada kepala sekolah saat data tersebut dibutuhkan.

2. Fitur tampilan laporan kegiatan. Dalam fitur ini akan ditampilkan data berupa hasil kegiatan yang telah dilakukan untuk dievaluasi oleh kepala sekolah.

3. Fitur tampilan data infrastruktur sekolah. Dalam fitur ini akan ditampilkan datadata infrastruktur sekolah oleh pihak tata usaha, sehingga dapat diserahkan langsung kepada wakil kepala sekolah bidang sarana dan prasarana saat data tersebut dibutuhkan.

\section{- Management Information system}

Di dalam management information system level 5 terdapat proses-proses diantaranya sebagai berikut :

1. Proses pengelolaan data sarana dan prasarana. Dalam proses ini pihak tata usaha sekolah akan mendata sarana dan prasarana yang ada di sekolah dan yang dibutuhkan sekolah melalui media komputer.

2. Proses penjadwalan kegiatan belajar mengajar. Dalam proses ini pihak kurikulum sekolah akan mengatur jadwal kegiatan belajar mengajar dan disimpan dalam suatu database.

3. Proses pengelolaan kurikulum. Dalam proses ini pihak wakil kepala sekolah bagian kurikulum akan membuat susunan kurikulum dan menyimpannya dengan 
menggunakan komputer agar data yang sudah dibuat mudah untuk diakses kembali.

4. Proses manajemen organisasi sekolah. Dalam proses ini tata usaha dan pihak sekolah bagian kesiswaan akan bekerja sama mengatur kegiatan organisasi yang ada di sekolah.

Setelah mengetahui proses-proses diatas, maka di dalam management information system level 5 terdapat fitur-fitur sebagai berikut :

1. Fitur pengelolaan data sarana dan prasarana. Dalam fitur ini pihak tata usaha sekolah menampilkan data sarana dan prasarana yang ada di sekolah.

2. Fitur penjadwalan kegiatan belajar mengajar. Dalam fitur ini akan ditampilkan data jadwal yang telah dibuat oleh pihak kurikulum sekolah.

3. Fitur pengelolaan kurikulum. Dalam fitur ini pihak wakil kepala sekolah bagian kurikulum dapat menyusun kurikulum yang tepat untuk kelancaran kegiatan belajar mengajar.

4. Fitur manajemen organisasi sekolah. Dalam fitur ini akan ditampilkan kegiatan organisasi yang ada di dalam sekolah.

- Transaction processing system

Di dalam transaction information system level 5 terdapat proses-proses diantaranya sebagai berikut : biaya sekolah satu semester

1. Proses pembayaran biaya sekolah satu semester. Dalam proses ini siswa akan diminta untuk membayar biaya sekolah satu semester kepada bagian tata usaha.

2. Proses transaksi penerimaan dan pengeluaran kas. Dalam proses ini bagian tata usaha akan mencatat dan memasukkan semua data penerimaan dan pengeluaran kas sekolah ke dalam komputer.

Setelah mengetahui proses-proses diatas, maka di dalam transaction information system level 5 terdapat fitur-fitur sebagai berikut :

1. Fitur pembayaran biaya sekolah satu semester. Dalam fitur ini bagian tata usaha akan menampilkan data siswa yang sudah melakukan pembayaran biaya sekolah satu semester.

2. Fitur transaksi kas. Dalam fitur ini bagian tata usaha akan menampilkan dan mendata semua penerimaan dan pengeluaran kas sekolah

\section{KESIMPULAN}

Kesimpulan penelitian ini adalah sekolah memiliki banyak sekali proses didalamnya. maka dari itu dibutuhkan sistem informasi yang bisa mengatur proses-proses di sekolah tersebut dengan baik. Dan penggunaan konsep ERP untuk merancang sebuah sistem informasi di sekolah ternyata bisa membuat proses-proses di sekolah lebih terarah dan memiliki alur proses yang jelas. Dan dengan arsitektur ERP berdasarkan tingkat kematangan CMM, sekolah bisa menerapkan sistem informasinya berdasarkan tingkat kematangan proses yang sesuai. Dengan begitu sekolah akan bisa mengembangkan sistem informasi nya dengan mudah. Dengan rancangan arsitektur ERP sekolah dengan penjelasan masingmasing fitur pada sistem informasinya yang dibuat berdasarkan tingkat kematangan CMM ini, diharapkan bisa diimplementasikan dan bisa menambah kualitas pada sekolah.

\section{REFERENSI}

[1] R. Al Aziz, F. Amalia, and A. Hendra Brata, "Pembangunan Sistem Enterprise Resource Planning pada Griya Laundry," J. Pengemb. Teknol. Inf. dan Ilmu Komput. Univ. Brawijaya, vol. 2, no. 6, pp. 2278- 
2285, 2018.

[2] D. Pratama, W. Witjaksono, and N. Ambarsari, "Penerapan Sistem Informasi Berbasis Enterprise Resource Planning Menggunakan SAP Modul Plant Maintenance di PT. Len Industri," Sisfo, vol. 06, no. 01, pp. 37-50, 2016, doi: 10.24089/j.sisfo.2016.09.003.

[3] M. A. Yaqin and S. -, "Pemodelan Aplikasi Enterprise Resource Planning Untuk Pondok Pesantren (Pemodelan Aplikasi Proses Akademik)," Matics, vol. 8, no. 1, p. 21, 2016, doi: 10.18860/mat.v8i1.3479.

[4] M. A. Yaqin et al., "ANALISIS DAN PENGGUNAAN CAPABILITY MATURITY MODEL PADA PONDOK," no. February 2020, 2019.

[5] F. A. Joansyah, M. Saiful, R. Hanafi, and R. G. Simamora, “Analisis dan Pengukuran CMM ( Capability Maturity Model ) pada Sekolah," pp. 25-34, 2019.

[6] P. Ilmiah, A. J. I. H. Purnomo, P. S. Informatika, F. Komunikasi, D. A. N. Informatika, and U. M. Surakarta, "Sistem informasi eksekutif pada sistem informasi pengembangan sumber daya manusia universitas muhammadiyah surakarta," 2017.

[7] L. O. Ismail and R. Sinen, "Penerapan Sistem Informasi Manajemen Pendidikan Dalam Proses Pembelajaran Di Smp Negeri 21 Makassar,” Idaarah J. Manaj. Pendidik., vol. 1, no. 2, pp. 290-309, 2017, doi: 10.24252/idaarah.v1i2.4272.

[8] P. C. Gainau and E. P. Kurniawati, "Evaluasi Sistem Pemrosesan Transaksi Dalam Menunjang Keunggulan Kompetitif Di Universitas Kristen Satya Wacana,” pp. 1-10, 2013. 